\title{
FROM HYSTERICAL PSYCHOSIS TO REACTIVE DISSOCIATIVE PSYCHOSIS
}

\author{
Onno van der Hart \\ Eliezer Witztum \\ Barbara Friedman
}

This article was accepted for publication under the Editorship of Charles R. Figley.

${ }^{2}$ Regional Institute for Ambulatory Mental Health Care, Amsterdam South/New West, Amsterdam, The Netherlands. To whom reprint request should be addressed at Riagg Z/!N W, P.O. Box 71505, 1008 DA Amsterdam, Netherlands.

${ }^{3}$ Jerusalem Mental Health Center-Ezrath Nashim, Jerusalem, Israel. ${ }^{4}$ Dissociative Disorders Institute, Los Angeles, California

\begin{abstract}
In this paper Reactive Dissociative Psychosis (RDP) is seen as a post-traumatic stress response and as a subcategory of Brief Reactive Psychosis (BRP). A review of the literature and the evolution of RDP from Hysteria and Hysterical Psychosis are given. Issue is taken with defining the duration of BRP as "Brief_ "The authors argue that long-standing psychotic symptoms may be traumatically-induced. The dissociative aspects of RDP as its key feature and the concomitant implications for accurate diagnosis are proposed. The usefulness of applying hypnosis in RDP treatment is summarized in a case study from Janet and detailed in a case from the authors' practice.
\end{abstract}

KEY WORDS: hysterical psychosis; reactive dissociative psychosis; brief reactive psychosis: posttraumatic stress; dissociation; traumatic grief; hypnotherapy. 


\section{INTRODUCTION}

Historically, Hysterical Psychosis was a rubric used to designate a vast amount of posttraumatic psychopathology. Recent advances in the field of traumatic stress now provide the means to differentiate categories of traumatic stress responses. A notable factor in this process was discovering the role of dissociation as a primary defense in overwhelming life events. Acknowledgment of dissociation in trauma will be established in the DSM-IV, which will contain a diagnostic category for acute stress reactions probably called Brief Reactive Dissociative Disorder. It is useful to trace the evolution of dissociation in psychology through the history of hysteria, specifically, hysterical psychosis.

The concept of hysterical psychosis (HP) suffered a curious fate in the history of psychiatry. During the second half of the $19^{\text {th }}$ century this disorder was wellknown and thoroughly studied, particularly in French psychiatry. In the early $20^{\text {th }}$ century the diagnosis of hysteria, and of HP, fell into disuse. Patients formerly considered to suffer from HP were diagnosed schizophrenics or malingerers. A few clinicians have attempted to reintroduce this diagnostic category, but it has not regained official recognition. One reason may be that for many other clinicians the term "hysterical" has pejorative connotations. The Index of the DSM-III$\mathrm{R}$ (APA, 1987) contains HP, then refers readers to either Brief Reactive Psychosis or to Factitious Disorder with psychological symptoms. Brief Reactive Psychosis, first included in the DSM-II (APA, 1968), was considered a response to major stress, such as the loss of a loved one or the psychological trauma of combat. Since evidence exists that a Reactive Psychosis is not always brief (Breuer, 1895; Janet, 1984/5; Van der Hart and Van der Velden, 1987), we report a recent case study collaborating this position. In reviewing early and recent literature on this posttraumatic stress syndrome, we will emphasize the essential role of traumatically-induced dissociation in the genesis of reactive psychosis. The description and discussion of our case example demonstrate the usefulness of this dissociative component in forming both a diagnostic impression and treatment approach, especially in conjunction with hypnotherapy.

\section{REVIEW OF THE LITERATURE}

During the past century and a half, many publications on Hysterical Psychosis (HP) referred to its traumatic origins. Important observations were also made about the phenomenology of HP and its curability through psychotherapy, particularly with the use of hypnosis. Unfortunately, many of the authors documenting their cases concentrated on symptomatology and treatment rather than including the etiological factors in HP. Ignoring this essential aspect detracted from the importance of trauma in the onset of certain disorders.

The role of trauma in the genesis of psychopathology is being reexamined in the light of new information emerging in the fields of trauma and posttraumatic psychopathology. This information requires assimilation with the historical thinking that precedes. In the case of reactive psychosis, we use the traditional nomenclature of $\mathrm{HP}$ in reviewing the literature and propose a new category of psychopathology-Reactive Dissociative Psychosis (RDP). RDP integrates the classical features of HP with the most -event thinking on trauma-induced psychosis. In this paper we refer to the literature and summarized cases with the term HP, then designate our case and discussion as RDP, a term we find relevant and useful in today's clinical experience.

One of the first historical reports of HP in which traumatic origins were clearly described and made the focus of treatment was published in 1868 (Hoek, 1868; cf. Van der Hart and Van der Velden, 1987). It concerned Rika van B., a young woman treated by the Dutch physician Andries Hoek in 1851/2. Her traumata included repeated abuse, rape, the drowning )f a servant, and finally her fiancé's suicide by drowning when she broke her engagement. Rika decompensated in response to his suicide. Her symptoms included periods of continuous talking and raving; the dissociative symptoms of amnesia, hallucinations and pseudo-epileptic seizures; depression; and suicidal urges. She experienced intense re-enactments of he traumatic events, for which she was amnestic afterwards. In the hypnotic state, however, she was very lucid; she could explain what was the matter with her and give directions to her physician regarding the course of treatment Thus, it was of utmost important in her cure that in the hypnotic state she had the ability to narrate her traumas calmly.

Unfortunately, Hoek's important case stood alone. It is true that his French contemporaries, notably Moreau de Tours (1845, 1855, 1865, 1869), ${ }^{\text {we }}$ re also studying $\mathrm{HP}$, but they were more preoccupied with describing its resenting characteristics than with its traumatic origins and its treatment in conjunction with this etiology. They found the following four basic features of HP: (1) its similarity to dreams, (2) its curability (using psychotherapy), (3) its plasticity or polymorphism, and (4) its analogy with chemically-induced (e.g., hashish) "artificial delirium." It was only through the works of Janet, Breuer and Freud that a more complete understanding of trauma-induced HP was possible. 


\section{HYSTERICAL PSYCHOSIS IN PIERRE JANET'S DISSOCIATION THEORY}

Following Moreau de Tours and others, Pierre Janet, the most imortant French authority on hysteria and HP, emphasized that HP constitutes a kind of waking dream in which the subject eventually cannot differentiate between the dream elements and normal perceptions Janet, 394/5, 1901). "Hystericals dream very much during the night and even during the day. (...) These dreams have usually two characteristics: (1) They take place in abnormal states or subconsciously. They disturb the normal thought by diminishing the disposable force of attention, but they do not mingle with it. (2) They run generally on a small number of subjects, and these subjects are always the same. The dream may increase under various circumstances, become complicated in all its smallest incidents, and mingle with the normal perception” (Janet, 1901, p. 460).

Through clinical observation of numerous hysterical patients, Janet established that these so-called dreams were related to traumatic experiences (Janet, 1889, 1898a, 1911; cf. Van der Kolk et al., 1989). Some of them were traumatic memories, i.e., reexperiences of a trauma. Janet labeled these primary idées fixes or primary emotional states (Janet, 1894, 1898b). Others were "dreams" and fantasies based upon these traumatic memories, and were called secondary idées fixes or secondary emotional states (cf. Van der Hart and Friedman, 1989). Janet considered traumatic memories and related secondary idles fixes as dissociative phenomena. He defined dissociation as the splitting off, separation and isolation of certain parts ("systems of ideas and functions") of the personality from the conscious awareness and control of one's habitual personality. These parts of the personality often remain unknown to waking consciousness and start to lead lives of their own. They alternate with conscious awareness in dominating the patient's behavior, or interfere with conscious awareness (cf. Van der Hart and Horst, 1989). The simplest dissociative phenomena are the primary and secondary idles fixes mentioned above. The most complex are the alter-personalities of patients suffering from multiple personality disorder (MPD), which have their own identity and distinguish themselves from the habitual personality.

According to Janet (1894/5), a psychosis could be considered hysterical if its dissociative nature could be established. The criteria for that are: (1) the psychosis is embedded in dissociative phenomena, (2) the psychosis itself should be a dissociated mental state, (3) a splitting or doubling of the mind (dédoublement de la personnalité) occurs, (4) subconscious phenomena exist, and (5) altered states of consciousness occur. As we understand Janet, the subject experiences $\mathrm{HP}$ as a waking dream based on a traumatic experience (Janet, 1894, 1898b). The subject presents in a delusional state which has no apparent connection to his or her current reality. However, the therapist may discover that it has direct connection to a past reality.

Janet believed that HP can develop progressively. Initially, a certain sequence of images (e.g., the reenactment of a traumatic event) dominates the mind during an hysterical attack. This traumatic content may also occur during intervals between the attacks, finally manifesting as a chronic psychosis. Janet speculated that the latter represented the transformation from HP into another form of mental illness.

Janet concurred with the observation of old masters that HP was curable by means of psychotherapy. He attributed this to the fact that the dissociative nature of hysteria implies a high hypnotizability. Hypnotherapy was thus the treatment of choice in these cases (cf. Van der Hart et al., 1989). One of Janet's examples illustrating this principle concerned the case of Achille, 38, a business man with no prior history of pathology, presenting with unintelligible speech and actions (Janet, 1894/5; cf. Nemiah, 1974; Witztum and Van der Hart, 1992). Achille saw and heard demons, felt possessed by them, and behaved bizarrely. Viewing this state as symptomatic, Janet believed there was another state, dissociated from this one, in which Achille could explain his illness (as with the case of Hoek's patient Rika van B.).. Evoking this dissociated state through hypnosis, Janet elicited a lucid account of the events that determined the content of Achille's delusional ideation. Rather than being proof of a psychotic disorder, the delusional phenomena and state proved to be symbolic references to a traumatic event so overwhelming that it was dissociated, the traumatic event was inarticulable and produced what appeared as a psychotic state. Treatment consisted of neutralizing the emotionally overwhelming event by working through memories of the material using a variety of hypnotic and psychotherapeutic techniques. After 1 month, the "demons" were vanquished and disappeared. Achille no longer went into deep hypnotic states, and pathological ideation ceased, indicating resolution of the traumatically induced dissociation. The HP produced by the dissociated trauma remitted completely, unity of mind was reestablished, 3- and 7year follow-ups indicated Achille was doing well in all respects.

The early views of Breuer and Freud (1893/5) on hysteria and HP were strongly influenced by Janet, as Breuer (1895) testified. They emphasized, among other things, the traumatic origins of these disorders. Breuer 
(1895) also pointed to the dream-like nature of HP and to the often rapid alternation of such dreams with the normal waking state. He believed that patients dreaming these waking dreams were in a state of self-hypnosis that the French termed "somnambulism." Unlike Freud, Breuer believed that such "psychotic states" could persist for a long time, as exemplified by his famous case of Anna $\mathrm{O}$.

\section{THE DECLINE OF HYSTERIA}

At the beginning of the $20^{\text {th }}$ century, interest M HP, hysteria and hypnosis vanished. That psychological trauma could be a major factor in the development of these disorders was also forgotten. The few attempts to establish the clinical validity of HP were not accepted (cf. Regis, 1906; Mairet and Salager, 1911). Two factors prompted this rejection: (1) The successful campaign against hysteria as a respectable mental disorder because it lacked an organic base (Villechenoux, 1968; Maleval, 1981). Babinski (1901, 1909) strongly advocated this position. This success led to regarding patients suffering from HP as malingerers or as following suggestions. (2) Bleuler's introduction of the term "schizophrenia" (Bleuler, 1911/50) as a diagnostic entity encompassing widely divergent mental disorders, and the broad acceptance it gained (Rosenbaum, 1980; Maleval, 1981). Bleuler's influence was so great, that after 1911 the majority of psychiatrists, including Freud, no longer used the diagnosis of HP (Maleval, 1981).

Only very few authors continued to stress the importance of distinguishing between HP and other psychoses. The German psychiatrist Raecke (1915) emphasized the influence of extreme situational stress in the development of HP. The Dutch psychiatrist Breukink (1923) harked back to the work of Janet, other French masters, Breuer and Freud. According to Breukink, HP was characterized by the patient's high hypnotizability. Therefore it was readily accessible and treatable by hypnosis. However, the all-encompassing label of "schizophrenia" prevailed, and many authors struggle with the clinical problem of hysteria and of diagnosing psychoses which did not completely fit the diagnostic criteria of schizophrenia (e.g., Carrot et al., 1945; Claude, 1937; Courbon, 1937; Mallett and Gold, 1964).

\section{THE RETURN OF THE DIAGNOSIS OF HYSTERICAL PSYCHOSIS.}

After World War 11, several attempts were made to revive the concept of $\mathrm{HP}$. In line with Janet's dissociation model, the Dutch psychiatrist Hugenholz (1946) stated that HP can develop in individuals with hysterical characteristics who are exposed to traumatic events. These events evoke and reactivate earlier painful experiences and their associated affect such as resentment and hate. Patients with HP exhibit a lowering of consciousness, dreaming, fantasizing, staring, inattentiveness and abulia. The disorder can be complicated by other hysterical symptoms such as abasia, astasia and aphonia. According to Hugenholz, the duration of HP may vary from a couple of days to several months. When the psychosis disappears, other hysterical characteristics may continue to exist.

In France, Follin et al., (1961) returned to the old literature of Charcot, Janet, and others, and the early work of Freud and Breuer. They presented five cases of psychotic and hysterical patients, concluding that the unfortunate inability to distinguish between HP and schizophrenia often lead to "the most serious therapeutic errors.”

In America, the influential work of Hollender and Hirsch (1964) described two dominant characteristics of HP: (1) a sudden and dramatic onset temporarily related to a profoundly upsetting event or circumstance, and (2) a short duration of less than three weeks. Its manifestations include hallucinations, delusions, depersonalization and grossly unusual behavior. They believed that HP most commonly occurs when persons with hysterical personalities encounter trying life situations. The adjective "hysterical" is used here as a synonym of "histrionic," which is not what the old French masters such as Janet had in mind; for them, HP was dissociative psychosis.

Hirsch and Hollender (1969) distinguished three different modalities of HP: (1) as socioculturally sanctioned behavior, i.e., behavior determined by the prevailing belief system in a given culture; (2) as simulation of psychotic behavior; and (3) as true psychosis with disruption and breakdown of ego boundaries. Langness (1976) criticized the first modality by stating that HP is usually considered to be abnormal, both by the members of the culture and by the investigator. Hirsch and Hollender's second modality, simulation, seems to have influenced the DSM-III and the DSMIII-R where Factitious Disorder with psychological symptoms is regarded as one of the categories to which the term HP refers. This unfortunate position can be traced back to the turn of the century and the view held by Babinski and others that many hysterical patients were malingerers.

Richman and White (1970) considered HP to be associated with anxiety related to death, aggression and actual object loss. In line with them, Martin (1971) viewed HP as a response to disrupted object relations, particularly in the case of disturbed marriages. 
Siomopoulos (1971) described HP as a pattern of regressive behavior related to childlike thought activity and merging of fantasy and reality, thus joining the old views of Moreau de Tours and other French masters. Pankow (1973) emphasized the non-schizophrenic nature of HP.

\section{DISSOCIATION REDISCOVERED}

Janet's dissociation model reappeared in the work of Pringuet (1977) who underscored the dissociative aspects of HP, including the splitting or doubling of the personality, conversion symptoms so-called and suggestibility_ For Spiegel and Fink (1979), HP usually involves brief and intense periods of psychotic behavior, generally with graphic decompensation, severe environmental stress and rapid recompensation in individuals with other hysterical features. It remains unclear whether histrionic or dissociative phenomena comprise the "other hysterical features." These authors did not use the concept of dissociation, yet their view that patients with HP are highly hypnotizable (while patients who are schizophrenic and psychotic are not), corresponds with Janet's. Furthermore, they stated that the former have a poor response to antipsychotic medication, but will respond to individual and family therapy. Follin et al.'s (1961) warning that the confusion of both disorders may lead to "the most serious therapeutic errors," refers precisely to this point. Spiegel and Fink regarded HP as a spontaneous, undisciplined trance state, which they would most likely consider a dissociative phenomenon now (cf. Spiegel, Hunt and Dondershine, 1988).

Steingard and Frankel (1985) stated that dissociation underlies the fact that certain highly hypnotizable persons are prone to experience transient but severe psychotic states while in spontaneously occurring trance states. In harmony with the experiences of old masters such as Hoek, Janet and Breukink, they believed hypnotherapy to be the treatment of choice. In conclusion: our review of old and more recent publications which are positive with regard to the diagnosis of HP seems to indicate that HP is a traumatically induced dissociative psychosis, which is manifested in spontaneously occurring trance states. During these trance states either reenactments of traumatic experiences or more symbolic experiences related to the trauma occur. Furthermore, these reports agree on psychotherapy, in particular using hypnosis, as the treatment of choice. As indicated, we believe that the name Reactive Dissociative Psychosis (RDP) would do more justice to this trauma-based disorder and increase the likelihood of its recognition in contemporary clinical practice.
The following case report details an apt illustration of the basic features of Reactive Dissociative Psychosis. It also illustrates the efficacy of psychotherapy using hypnosis.

\section{AVRAHAM, PERSUCUTED BY A 'DEMON'}

In the following case example, hypnotherapy was the primary treatment modality, enabling the therapists to enter and transform the patient's dissociated experiences. Like related cases (cf. Aikins, 1923; Janet, 1894/5; Spiegel and Fink, 1979), the "devil" or a "demon" played an important role, and the patient's pathological imagery was transformed using hypnosis. The changes occurring during hypnosis led to behavioral changes which were then reinforced by various traditional psychotherapeutic techniques. On October 16, 1986, terrorists threw three hand grenades into a crowd near the Western Wall in the Old City of Jerusalem, killing one person and wounding 69. Two months later, Avraham, 35, an ultra-orthodox Israeli Jew was brought to a Mental Health Outpatient Clinic by his wife. During the intake session, Avraham frequently cried and moaned as if in physical pain. His affect was depressed. He was oriented to place and time, but not to current events. His cooperation with the therapists was so poor that it was impossible to evaluate accurately for a thought disorder. He denied any suicidal tendencies. Based on the fact that the clinician was unaware of the trauma history, a tentative diagnosis of Major Depressive Episode was made, and antidepressant medication (Imipramine, $150 \mathrm{mg}$.) was initiated. As the trial with medication was unsuccessful and the patient continue to deteriorate, Avraham was referred to the authors EW and OvdH for treatment.

Avraham, accompanied by his wife, attended therapy weekly. During the first 3 sessions, the following background information was gathered from Avraham's wife, as the patient hardly spoke. Avraham's past medical history was unremarkable and he had no previously defined psychiatric history. His father, Avraham's first Torah teacher, was in his time, a wellknown oriental orthodox rabbi in the Kabalist tradition. He was killed in a car accident when Avraham was 8 years old. His mother never recovered from her grief and was incapable of caring for Avraham and his 8 siblings. At the age of 12 he was placed in an orphanage. He studied in a series of orthodox Yeshivas (religious schools that emphasize Jewish studies to the exclusion of secular subjects). At 20, he married and had 5 children. As an observant Jew, Avraham frequently went to the Western Wall, the last remains of the Second Temple, the most sacred site in Judaism. Praying there was a continuation of his father's religious habits. Avraham was thus engaged during the 
evening when the hand grenades were thrown. He was not hit, but the force of the explosions threw him into the air. As far as he remembered, he had not been unconscious.

According to his wife, Avraham immediately returned home. She noted a marked change from his normal behavior over the next two weeks. He began talking to himself in fragmentary sentences, speaking constantly of bombs and people dying. He was easily startled and distracted. He lost interest in his family. In the third week, he began to consume huge quantities of food, even compulsively taking food from his childrens' plates. Over the next month, he gained more than $15 \mathrm{~kg}$, developing peripheral edema and episodes of cellulitis which required medical attention. During the fifth week he withdrew further, had extensive crying spells and was obviously depressed. He experienced severe sleep disturbances, including insomnia and periods of shouting _and crying during apparent sleep. He refused to bathe, shave, or change his clothes, completely neglecting personal hygiene and appearance. He was dismissed from the Yeshiva, and the family lost its sole source of income. Apart from his deranged behavior, which led his wife to bring him to the Clinic, the family's deteriorating economic situation became a stressful factor of increasing magnitude.

Despite the patient's initial presentation as psychotic, he was not responsive to Ridazine $(600 \mathrm{mg})$ which was withdrawn along with Imipramine after one month. Because the precipitating event was traumatic and followed by rapid deterioration, Psychotic depression, Brief Reactive Psychosis, and even Schizophreniform Disorder were possible diagnoses. However, the patient was not responsive to medication and his symptoms persisted for several weeks. Physical and neurological examination, including a CAT Scan, indicated no pathology.

The therapists began considering another possibility. They noticed severe regressive characteristics: Avraham's behavior resembled that of a frightened child-his affect was terrified rather than detached or remote. He showed no psychotic aggression. The content of his "delusions" was polymorphic, bizarre and colorful, but also ambiguous and vague. These features led to the formulation of another clinical impression: Avraham's symptomatology was a posttraumatic stress response with strong dissociative features. In the terminology proposed in this paper, it was thought that he suffered from a RDP. As more evidence emerged to support this position, the therapists initiated a treatment plan accordingly.

\section{TREATMENT}

Whenever the traumatic event at the Western Wall was mentioned in session, the therapists observed that Avraham made agitated arm movements: First upward and then back and forth horizontally. Following Janet, they regarded these movements as expressions of flashback phenomena-dissociative episodes during which Avraham reexperienced the trauma. They investigated the idea that these movements were iconic representations of overwhelming experiences during the attack-the explosions, people falling and running into each other in panic. When they inquired about this, the patient, who until then had barely spoken in sessions, verified it and started haltingly to explain what had happened. From then on, he could verbally communicate with the therapists.

During following sessions Avraham and his wife explained that his frequent prayers at the Western Wall had a dual nature: The religious purpose and an attempt to establish a rapport with his late father. The attack shattered Avraham's defenses against the unresolved traumatic grief following his father's untimely death. His subsequent compulsive eating was his effort to fill the deep emptiness he felt at the loss of his father. The therapists made this unresolved grief the focus of treatment. They asked Avraham to write a leave-taking letter to his father in which he could tell him everything he wanted and needed to tell him (cf. Van der Hart, 1983). Avraham's wife assisted him in this task and the letter he brought to the next session began with the words, "Father, father, father, why did you leave me? Why didn't you come when I was married?" The handwriting in the first sentence was appropriate for a 35-year old man, but it quickly degenerated into a disorganized pattern, with large letters typical of the handwriting of a young child, and by the end it had become scribble. Avraham was asked to read the letter aloud, and the same regression between episodes of screaming and hitting himself vigorously on the chest, and episodes of sinking into a state of masticatory movements of sucking and rocking back and forth. The traumatized child part of his personality reexperienced the intense grief of the loss of his beloved and powerful father. With deep emotion he' expressed the feeling that he would "forever be alone, that life would never be the same, and that forever there would only be a cloud of emptiness_" After this session, Avraham was very upset. The frequency of his nocturnal persecutory attacks increased and persisted into the day as well He began to eat even more. The rapid weight gain caused additional medical complications which often prevented him from attending the scheduled therapeutic sessions. The therapists realized their error in not exploring the nature of these intrusive episodes and decided to do so immediately.

The nocturnal persecutory attacks prompted by his 
unresolved mourning entailed terrifying experiences which occurred during sleep, the transition state from sleeping to waking, and finally, during the waking state itself. In them Avraham was threatened by a figure whom he initially described as "the Black." Additional information from himself and his wife, who kept a diary on these attacks, revealed that this very ugly figure was nonhuman, had red eyes and the legs and feet of a chicken, the stereotypical description of a demon in traditional Jewish folk religion. When this vision occurred, Avraham would run around the room shouting for help and hitting his head against the wall, trying vainly to shake off the frightening images. During this period he refused to leave the house and kept all windows and curtains closed because he felt people were trying to kill him.

To access and understand the whole picture, the therapists decided to use hypnosis as a means of entering and controlling these frightening dissociative experiences. Hypnosis was very easily induced. Avraham was directed to see the black figure who was mocking and threatening him: "I killed your father and now I will kill you like I killed your father.” Avraham also reported seeing his father standing in the shadows looking at him sadly. He cried to his father for help, but the father could not help him. He tried to escape from the black figure, but was unable to do so. He could admit that the figure was a "demon," a courageous admission in light of the cultural taboo against naming or discussing demons.

In the next sessions the therapists assisted Avraham in gaining some control over this demon. Under hypnosis he was given the traditional instructions for exorcising a demon. Whenever he saw the black figure, he was to incant loudly and clearly: "Go, go, go away, because you do not belong to our world." He used this incantation in hypnosis during the session and saw the "Black" running away. At home in the presence of his wife it was effective, but when Avraham tried to utter it alone it was not.

In order to promote Avraham's independent coping ability when alone with the demon, the therapists instructed him to demand forcefully that the "demon" give its name. This suggestion derived from traditional beliefs that knowing and identifying a demon by name is a prerequisite for overpowering it. Avraham rehearsed this during the session, but the "demon" refused to disclose its identity and ran away. To generate a greater sense of self-control, the therapists taught Avraham self-hypnotic relaxation techniques to practice at home with his wife's assistance. During the next session, he reported some improvement using these techniques. When he, in the company of his wife, demanded that the "Black" reveal its name, the “demon” again became frightened. "Black" now enlisted two aides, and this demonic triad tried, almost successfully, to drown Avraham when he was in the Miqveh (ritual bath). In session, under hypnosis, Avraham saw both aides, one of whom was changed into the form of a black dog. The therapists asked where "Black" was. Avraham fearfully replied that it was trying to sneak into the gutter over the room. The therapists instructed him to demand that "Black" reveal itself and state its name. With the therapists' support, Avraham complied. His insistence resulted in the "demon" and its aides running away.

Therapy reached a stalemate, as Avraham could not engage the demon. In the next session, Avraham was asked to visualize the setting where he had last seen the "demon" and its aides. "A desolate place in the desert," was his reply. The therapists interpreted this as a metaphoric kernel statement (Fernandez, 1977), expressing his problematic life situation. The "demon" and its two aides were hidden behind nearby boulders. The therapists urged Avraham to search for signs indicating the direction he should take in order to find protection. At first he saw nothing, then encouraged to scan the horizon, he found a distant, small spot of green. It was suggested that this might be an oasis where he could find shelter, water, food and the company he was looking for, the latter being an indirect suggestion for symbolically meeting his father. When the therapists suggested that Avraham walk in that direction, the "demon" and its aides immediately appeared, trying to distract him from going his own way. (This symbolized the struggle of separating and becoming independent.) He was asked to demand their names and to lure them toward him, holding them captive until they gave their names. The fact that they were still too afraid to approach him restored some self-confidence in the patient. At the end of the session he was asked how old he felt. "12," he answered: Older than before.

Avraham continued his imagery process at home with his wife's assistance. During the next session he was encouraged to persevere toward the "green," despite the obstacles and recurrent attacks of the "Black" triad. Avraham and his wife reported that at home the number of episodes involving the "demon" was greatly reduced, and Avraham felt more confident in his ability to control the "demon." During one therapy session the black dog suddenly appeared, and Avraham repelled it by throwing an imaginary stone. Afterwards he reported his age as 14 .

During the next session Avraham reported having found a new and powerful ally in his struggle with the demons: The very famous Tsaddik (righteous man), Rabbi Chaim Ben Attar (1696-1743). Avraham had visited the grave of the Rabbi on the anniversary of his death (Hillula) earlier that week. It is believed that such 
a pilgrimage on the death anniversary is an effective panacea (cf. Bilu and Abramovitch, 1985). A request made on this day at the grave of a Tsaddik will be granted. Avraham visited the grave on the Mount of Olives with many others, but afterwards remained there alone. He cried, asked for Help and prayed for many hours. Finally he felt that his prayers were answered. After that he felt supported by this Tsaddik and experienced himself as more powerful. (This event signified an important shift in the development of an internal locus of control. Without direct suggestions from the therapists, Avraham initiated action to solve his problem. He began assuming responsibility for his situation and enlisted the help of a wise and powerful father figure which he internalized.) At home, he worked with his wife to come closer to the green area, determined to reach it during the next session.

In this $18^{\text {th }}$ session, Avraham described the green area as a beautiful garden surrounded by a high wall. He circled it and found a gate. Approaching it, he smelled fragrant aromas from the garden. Suddenly, the "Black" and its aides tried to grab him and throw him in a pit; but with the power of the Tsaddik and the therapists' encouragement, he showed that the balance of power had definitely changed. He actually shouted to the "demons:" "In the name of Rabbi Chaim Ben Attar, I tell you, go away! I am not afraid of you. Go away. He invoked verses from the Psalms: "He that dwells in the secret place of the Most High shall abide under the shadow of the Almighty..." (Psalms 91, 1). He stood in the center of the therapy room, actually fighting with his arms and legs, until at last he overcame the "demons" and they withdrew, defeated. Next he approached the guardian at the gate, explained that he had to enter the garden, and asked permission to enter. (This reflected both Avraham's sense of entitlement and recognition of boundaries: two new behaviors that resulted from claiming his sense of power after conquering the demons.) From outside, he saw many beneficent, whitebearded Tsaddikim. Suddenly he saw his father among them, called to him and asked him to instruct the guardian to let him in. Avraham's affect changed remarkably as he informed his wife and therapists that he was entering the Lower Paradise, that the air smelled like perfume, and that he saw two springs of water. (Avraham's experience of the Lower Paradise was consistent with traditional descriptions of this wellknown place in Jewish mythology.) Encouraged to drink and satisfy his thirst, he described the water as sweet and fresh. He himself appeared completely revitalized.

Then he saw his father again and ran to him, embracing him and talking to him joyfully. He saw his admired grandfather, for whom he was named and embraced him also. Next he met his own Rabbi who had died in a traffic accident when Avraham was 18. He described these experiences with wonder, excitement and joy, using Biblical verses to express his feelings. At the end of the session, the therapists suggested that from then on Avraham would have the power of Rabbi Chaim Ben Attar with him, plus the additional protective power of the Tsaddikim, his father, grandfather and former Rabbi. Internalizing their positive qualities would enable him to be a more functional husband and father. Closing suggestions were given for a comfortable, uninterrupted sleep.

\section{FOLLOW-UP}

In the next and final session Avraham's wife brought no notes from home. For the first time in 6 months, "There was nothing to report." Avraham was sleeping well at night, and apparently all hallucinations and delusions had disappeared. Avraham felt very good, albeit a bit weak. He had spent considerable time in healthy interaction with his children. Both he and his wife felt that his visit to the Lower Paradise had been something of a mystic miracle, a great privilege which, traditionally, is granted to only a few very righteous men. Avraham did not want to undergo hypnosis again, as the experience in the Lower Paradise felt completed. During the preceding week, on the anniversary of his father's death, he had visited his father's grave and cried intensely. Afterwards, he felt greatly relieved. (This completed the mourning seen as therapeutically necessary to release the dissociated affect of the first traumatizing event.) The couple thanked the therapists, giving each of them a Book of Psalms as a gift. Avraham said that he prayed daily for their well-being. Soon afterwards the couple went on holidays, for the first time in their lives. Then their debts increased, they moved to a cheaper apartment, creditors hounded them, and they verged on starvation. Under these pressures, Avraham again experienced sleep disturbances. However, he did not decompensate or experience psychotic ideation. Three months after the final session a social agency provided the family with financial support and Avraham began a weight reduction program. Avraham's wife gave birth to another child 18 months later. At that time Avraham functioned relatively well. He experienced mild sleep problems and was a bit phobic of cars, but evidenced no psychotic or paranoid ideation or signs of depression. 


\section{DISCUSSION}

\section{REACTIVE DISSOCIATIVE PSYCHOSIS}

The immediate cause of RDP is usually a traumatic or stressful life event. The DSM-111-R category for Brief Reactive Psychosis indicates that BRP is a posttraumatic stress response, as is PTSD. We believe that in addition to environmental stressors, subjective factors are sufficiently traumatizing to produce a posttraumatic stress response. The terrorist attack in the case of Avraham illustrates the objective nature of the trauma. Avraham's enduring belief that his father abandoned him emphasized the subjective aspect. This case illustrates Janet's and Hugenholz's observations that in certain subjects a traumatic experience activates previous traumatic memories, giving rise to the phenomenon of double emotion (Janet, 1903, 1928). Double emotion results from the observation that traumatic memories can be triggered either by cognitive associations or by "new" emotions (Janet, 1904). In some cases, previous traumatic memories are activated, giving rise to the phenomenon of double emotion, relating to both past and present.

While it is recognized that PTSD may become chronic, in Brief Reactive Psychosis a short duration is regarded as a necessary condition. According to Hollender and Hirsch (1964), HP lasts no longer than 3 weeks; the DSM-111-R allows for a duration of one month for Brief Reactive Psychosis. Earlier references refer to a short duration, but add the possibility of frequent relapses.

Convincing arguments as to why this criterion is essential have not been given, however (cf. Jauch and Carpenter, 1988a\&b). Breuer's (1895) view that HP could just as well develop into a more chronic condition has never been refuted. Our case of Avraham and Janet's case of Achille, which we consider examples of Reactive Dissociative Psychosis, and other cases (Hoek, 1868; cf. Van der Hart and Van der Velden, 1987; Breukink, 1923; Hugenholz, 1946) support the notion of a longer duration. It is possible that chronic RDP becomes another kind of disorder, as Janet (1893/1901) speculated, and this, too, requires further study.

We believe that the essential characteristic for accurate diagnosis of RDP is not a short duration, but a dissociative foundation. It could, therefore, also be argued that RDP should be placed under the category of the dissociative disorders, just like the Brief Reactive Dissociative Disorder.

\section{DISSOCIATION AS A RESPONSE TO TRAUMA}

The dissociative foundation of RDP is a more meaningful explanatory principle than an hysterical or histrionic character as currently indicated in the
DSM-III-R. Dissociating the experiencc from normal consciousness is the primary defense against trauma (Janet, 1889, 1894, 1911; Putnam, 1985, 1989; Spiegel, 1986, 1988). Dissociation leads to the formation of mental systems outside the experiencing ego (dédoublement de la personnalité), as Janet and his contemporaries observed. In their simplest form these systems consist of "traumatic memories." These traumatic memories can, however, become more complex, establish a sense of self, and develop into the alter-personalities which characterize Multiple Personality Disorder. In the case presented, the traumatic memories were organized around a demonic figure which provided the means for investigating the dissociated experience. We propose that for a psychosis to be RDP, its dissociative nature must be established.

According to Janet, this is apparent in the alteration of different states of consciousness, the existence of subconscious phenomena, and high hypnotizability. This alteration of states of consciousness is referred to in modern literature as the intrusion of traumatic memories, flashbacks and nightmares. The rapid and persistent intrusion of these traumatic phenomena into normal daily life creates an alternative reality in which the subjects experience themselves; at best the intrusion is minimal, at worst, it alternates increasingly with current reality until it dominates (Friedman, 1989). We suggest that RDP occurs at the stage when a patient experiences significantly diminished periods of normalcy, and immersion in the traumatic phenomena becomes pervasive. It is the subjective experience of this dual reality that distinguishes the psychotic feature of RDP.

While the disturbance resulting from posttraumatic psychopathology may at some stage produce psychotic features, psychotic behavior and ideation do not persist once their traumatic origins in reality have been identified. In fact, it is this discovery of the correct reality which seems to cause symptoms to subside. As our example illustrates, even when the patient's behavioral responses do not seem appropriate to the present reality, the patient can narrate the delusional content, comment on it as an observer, recall and refer to it after experiencing it. These are the functions most often impaired in psychosis. To clinicians schooled in the principles of traumatic flashbacks and reenactments, the.. patients' responses are, in fact, appropriate to their subjective experiences at the time. Furthermore, when their posttraumatic (RDP) episodes are resolved, patients return to their former levels of functioning, indicating that the nature and degree of organization in thought processes was operational prior to the trauma.

Other authors emphasize high hypnotizability, which they, too, consider to be dissociative in nature (Breukink, 1923; Spiegel and Cardena, 1990; Spiegel 
and Fink, 1979; Steingard and Frankel, 1985). Our patient showed a great trance capacity, as did Janet's, although Achille was initially difficult to hypnotize.

\section{HYPNOTHERAPY}

It is known that patients with dissociative states, acute and chronic alike, do not respond well to medication. In their textbook Klein et al., (1980) remark about dissociative reactions, that "these reactions are essentially refractory to psychopharmacological treatment” ( $p p$. 560/1). With regard to MPD, there is no evidence that medication of any type has a direct therapeutic effect on the dissociative process as manifested in this severe dissociative disorder (Barkin et al., 1986). As for $\mathrm{RDP}$, there are case reports confirming and supporting the clinical observation that these patients do not respond well to psychopharmacology (Spiegel and Fink, 1979; Steingard and Frankel, 1985; Waldfogel and Mueser, 1988). This is clearly an area which has been insufficiently studied. Therefore, our conclusion must be regarded as tentative, and further study is urgently needed.

The fact that patients with RDP usually have a high degree of hypnotizability suggests that psychotherapy, particularly with the use of hypnosis, may be the treatment of choice (cf. Breukink, 1923; Janet, 1898a; Spiegel and Fink, 1979; Steingard and Frankel, 1985). Hypnosis can be used to identify and influence the traumatic experiences that produced the psychotic ideation. In Avraham's case, hypnosis was used to learn the nature of his subjective experience of the demon, enabling the therapists to instruct the patient in defending against it. The nonhypnotic treatment technique of letter-writing intensified his demonic hallucinations. To be effective for him, the patient needed to formulate a defense system based on traditional mystical sources that were part of his cultural background. The therapists then used the hypnotic technique of guided imagery to transform the patient's metaphoric kernel statement of desolation into a more positive one (cf. Van der Hart, 1986; Witztum et al., 1988). In imagery, the patient's arduous journey from the desert to the green spot ended in a joyful reunion with his father in the Lower Paradise. This event in the imagery domain coupled with the actual visit to his father's grave constituted the resolution of his chronic, traumatic grief (cf. Van der Hart et al., 1990).

Our conclusion that psychotherapy using hypnosis may be the treatment of choice for patients with RDP is, in fact, based on a limited number of both contemporary and historical case studies, not on systematic research. This approach is in need of careful study under prospective and rigorous experimental conditions.

\section{CULTURAL ASPECTS}

Avraham's case aptly illustrates Langness' (1976) position against RDP as socioculturally sanctioned behavior. His visual hallucinations fit Wing, Cooper and Sartorius' (1974) definition of a dissociative hallucination. Although the demons and Tsaddikim in Avraham's dream were collective symbols in a "particularized mythic world" (Dow, 1986), his behavior was clearly seen as abnormal in his community and even led to his dismissal from the Yeshivah. For successful treatment, it was essential to join and validate this "mythic world" as well as the more general cultural background of the patient (cf. Bilu et al., 1989). Using traditional counter demonic measures such as incantations, the examination of the real form of the "Black" and its aides, the demands that it reveal its name and identity, and the therapists' integration of the patient's own language via reiterations, blessings, prayers and Biblical verses in their communications accomplished this task.

\section{CONCLUSION}

Theoretical notions about the symbolic and dissociative nature of trauma-induced Reactive Dissociative Psychosis were conceptualized a century ago as Hysterical Psychosis. HP reexamined through knowledge of trauma in historical and current case studies, suggests that this disorder can be diagnosed as a form of posttraumatic stress disorder with dissociation as its dominant feature. In the absence of response to psychotropic medication, psychotherapy with hypnosis could in some cases provide an effective treatment approach. A recent traumatic event can trigger and combine with past traumata in forming the representational nature of the symptomatology. Awareness that the content of traumata can appear in symbolic form alerts the clinician to go beyond the obvious conceptualization of psychosis and thoroughly observe subjects' thought processes and orientation to reality over time. Hypnotic procedures may help therapists enter the patient's world, join and utilize the patient's idiosyncratic symbols and cultural symbology to transform this inner world. We suggest that when a psychotic presentation follows a traumatic event, this approach to Reactive Dissociative Psychosis may in certain cases provide effective treatment in the recovery from posttraumatic stress. Certainly more, and more systematic, studies are needed. 


\section{REFERENCES}

Aikins, H.A. (1923). Casting out a ‘stuttering devil.’ J. Abnorm. Social Prychol. 18: 137-152. In Murphy G. (ed.), An Outline of Abnormal Psychology, The Modern Library, New York, 1929, pp. 175-192.

American Psychiatric Association (1968). DSM-111, Washington, DC: Author. American Psychiatric Association (1987). DSM-III-R, Washington, DC: Author. Babinksi, J. (1901). Definition de 1'hystérie. Rev. Neurol. 9: 1074-1080.

Babinski, J. (1909). Demembrement de I’hystérie traditionelle. Pithiathisme. La Semaine Médicale 59(1): 3-8.

Barkin, R., Braun, B. G. , and Kluft, R. P. (1986). The dilemma of drug treatment for multiple personality disorder. In Braun, B. G. (ed.), Treatment of Multiple Personality Disorder, Washington, DC: American Psychiatric Press, pp. 109-132.

Bleuler, E. (1911). Dementia praecox oder Gruppe der Schizophrenien. In Aschaffenburg, G. (ed.), Handbuch der Psychiatrie, spezieller Ted 4 Abt. I. Vienna: F. Deuticke.

Bleuler, E. (1950). Dementia Praecox or the group of schizophrenias. International Universities Press, Madison.

Bilu, Y., and Abramovich, H. (1985). In search of the Saddiq: Visitational dreams among Moroccan Jews in Israel. Psychiatry 38: 145-159.

Bilu, Y., Witztum, E., and Van der Hart, O. (1989). Paradise regained: 'Miraculous healing' in an Israeli psychiatric clinic. Cult. Med. Psychiatry, 14, 105-127.

Breuer, J., and Freud, S. (1893/95). On the psychical mechanism of hysterical phenomena: A preliminary communication. In Strachey, J. (Transl. and Ed.), The Standard Edition of the Complete Psychological Works of Sigmund Freud, Vol. 3. London: Hogarth Press, 1955, pp. 53-69.

Breuer, J. (1895). Theoretical. In Strachey, J. (Transl. and Ed.), The standard Edition of the Complete Psychological Works of Sigmund Freud, Vol. 3. Hogarth Press, London, 1955, pp. 259-333.

Breukink, H. (1923). Over de behandeling van sommige psychosen door middel van een bijzondere vorm der kathartisch-hypnotische methode. Tijdschrift voor Geneeskunde 67: 1321-1328.

Carrot, E., Charlin, A., and Remond, A. (1945). L’hystdro-catatonie. Annal. Med. Psychol. 103: 1, 347-353.

Claude, H. (1937). Rapport de I’hystdrie avec la schizophrdnie. Annal. Mid. Psychol. 95: 11, 1-14, 141-164 (Discussion).

Courbon, P. (1937). Hystérie, schizophrénie, pithiatisme et simulation. Annal. Mid. Psychol. 95: 11, 257-268

Dow, J. (1986). Universal aspects of symbolic healing: A theoretical analysis. Am. Anthropol. 7: 333-375.

Fernandez, J. W. (1977). The performance of ritual metaphor. In Sapir, J. D. and Crocker, J. C. (ids.), The Social Use of Metaphor, University of Pennsylvania Press, Philadelphia, pp. 100-131.

Follin, S., Chazaud, J., and Pilon, L. (1961). Cas cliniques de psychoses hystériques. Evol. Psychiatr. 26: 257-286.

Friedman, B. (1989). Post-traumatic stress disorder and dissociation, response versus disorder. Paper presented at the Second Annual Conference on Multiple Personality and Dissociation. Costa Mesa, California.

Hirsch, S. J., and Hollender, M. H. (1969). Hysterical psychosis: Clarification of a concept. Am. J. Psychiatry 125: 81-87.

Hoek, A. (1868). Eenvoudige mededelingen aangaande de genezing van eene krankzinnige door hit leversmagnetismus. 's Gravenhage: De Gebroeders van Cleef.

Hollender, M. H. and Hirsch, S. J. (164). Hysterical psychosis. Am. J. Psychiatry 120: 1066-1074. Hugenholz, P. Th. (1946). Kliniek der psychogene psychosen. In van der Horst L. (ed.), Anthropologische psychiatric, Deel H. Randpsychosen, Van Holkema \& Warendorf, Amsterdam, pp. 415-478.

Janet, P, (1889). Automativme psychologique, Fdlix Alcan, Paris. Reprint: Société Pierre Janet, Paris, 1974.

Janet, P. (1893). Contribution á l'étude des accidents mentaux chez les hysteriques. Thèse médicale. Paris: Reuff \& Cie. Also in: P. Janet (1911), L'Etat mental des hysteriques (second edition), Fdlix Alcan, Paris. Reprint: Lafitte Reprint, Marseille, 1984.

Janet, P. (1894). Histoire d'une idle Fixe. Rev. Philos. 37: 121-168. Also in: P. Janet (1898), Nevroses et idées fixes, Vol. 1. Paris: Félix Alcan, pp. 156-212.

Janet, P. (1894/5). Un cas de possession et l'exorcisme moderne. Bulletin de l'Universite de Lyon, Dec. 1894Jan. 1895, 41-57. Also in: P. Janet (1898), Nevroses et idées fixes, Vol. 1, Paris: Fdlix Alcan, pp. 375-406.

Janet, P. (1898). Nevroses et idees fixes, Vol. 1. Paris: Félix Alcan. (a)

Janet, P. (1898). Traitement psychologique de l’hystérie. In Robin, A. (ed.), Traité de therapeutique appliquée. Paris: Rueff. (b) Also in: P. Janet (1911), LEtat mental des hystériques, sec. ed. Paris: Félix Alcan. 
Janet, P. (1901). The Mental State of Hystericals, Putnam \& Sons, New York. Reprint: University Publications of America, Washington, DC, 1977.

Janet, P. (1903). Les obsessions et la psychasthénie (2 volumes). Fdlix Alcan, Paris. Reprint: Arno Press, New York, 1976.

Janet, P. (1904). L’Amnésie et la dissociation des souvenirs par l »émotion. J. Psychol. 1: 417-453. Janet, P. (1911). L'Etat mental des hystériques (second edition), Fdlix Alcan, Paris. Reprint: Lafitte Reprints, Marseille, 1984.

Janet, P. (1928). De !'angoisse d l'extase, Vol. 2: Les sentiments fondamentaux. Félix Alcan, Paris. New edition: Socidtd Pierre Janet, Paris, 1975.

Jauch, A. D., and Carpenter, W. T. (1988). Reactive psychosis, 1. J. Nerv. Mental Dis. 176: 72-81. (a)

Jauch, A. D., and Carpenter, W. T. (1988). Reactive psychosis, 11 J. Nerv. Ment. Dis. 176: 82-86. (b)

Klein, D. F., Gittelman, R., Quitkin, F., and Rifkin, F. (1980). Diagnosis and Drug Treatment of Psychiatric Disorders. Adult and Children. Williams \& Wilkins, Baltimore.

Langness, 1. (1976). Hysterical psychoses and possessions. In Lebra, W. P. (ed.), Culture-Bound Syndromes, Ethnopsychiatry, and Alternate Therapies, The University Press of Hawaii, Honolulu, pp. 56-67.

Mairet, A., and Salager, E. (1910). La folie hystérique, Coulet et Fils, Montpellier. Maleval, J. M. (1981). Folies hystériques el psychoses dissociatives, Payot, Paris.

Mallett, B. L., and Gold, S. (1964). A pseudo-schizophrenic hysterical syndrome Brit. J. Med. Psychol. 37: 59-70.

Martin, P. A. (1971). Dynamic considerations in the hysterical psychosis. Am. J. Psychiat. 128: 101-104.

Moreau de Tours, J. J. (1845). Du hachisch et do l 'aliénation mentale. Paris: Librairic do Fortin, Masson et Cie. English edition: Hashish and mental illness, Raven Press, New York, 1973. Moreau de Tours, J. J. (1855). De l'identité de l'état do rêve et do la folie. Annal. Med. Psychol, $3^{\mathrm{e}}$ serie, 1, 361-408.

Moreau de Tours, J. J. (1865). De la folie hystérique et de quelques phénomenes ner-veux propres d 1 hystérie convulsive, a 1 hystéro-épilepsie et v I epilepsie, Masson, Paris.

Moreau de Tours, J. J. (1869). Traité pralique de la folie nevropathique (vulgo hysterique), Germer Baillière, Paris.

Nemiah, J. C. (1974). Conversion: Fact or chimera? J. Psychiatry Med. 5: 443-448.

Pankow, G. W. (1974). The body image in hysterical psychosis. lit. J. Psychoanal. 55: 407-414. Prinquet, G. (1977). A propos d’un cas de psychose hystérique. Nouv. Press. Med. 6: 441-443. Putnam, F. (1985). Dissociation as a response to extreme trauma. In Kluft, R. P. (ed.), Childhood Antecedents of Multiple Personality, American Psychiatric Press, Washington, DC, pp. 65-97.

Putnam, F. (1989). Pierre Janet and modern views of dissociation. J. Traum t. Stress 2: 413-429. Raecke (1915). Ueber hysterische and katatonische Sit uationspsychosen. Arch. Psychiatr. Nervenkr. 55: 771-780.

Regis, E. (1906). Précis de psychiatrie (third edition), Octave Doin, Paris.

Richman, J., and White, H. (1970). A family view of hysterical psychosis. Ain. J. Psychiatry 127: $280-285$.

Rosenbaum, M. (1980). The role of the term schizophrenia in the decline of diagnosis of multiple personality. Am. J. Psychiatry 37: 1383-1385.

Siomopoulos, V. (1991). Hysterical psychosis: Psychopathological aspects. Brit. J. Med. Psychol. 44: 95-100.

Spiegel, D. (1986). Dissociating damage. Am. J. Clin. Hypn. 29: 123-131.

Spiegel, D. (1988). Dissociation and hypnosis in post-traumatic stress disorders. J. Traum. Stress 1: 3-16.

Spiegel, D., and Cardeña, E. (1990). New use of hypnosis in the treatment of posttraumatic stress disorder. J. Clin. Psychiatry 51 (Suppl.): 39-43.

Spiegel, D., and Fink, R. (1979). Hysterical psychosis and hypnotizabilily. Am. J. Psychiatry 136: 777-781.

Spiegel, D., Hunt, T., and Dondershine, H. E. (1988). Dissociation and hypnotizability in posttraumatic stress disorder. Am. J Psychiatry 145: 301-305.

Steingard, S., and Frankel, F. H. (1985). Dissociation and psychotic symptoms. Am. J. Psychiatry 142: 953-955.

Van der Hart, O. (1983). Rituals in Psychotherapy, Irvington, New York.

Van der Hart (1986). Metaphoric and symbolic imagery in the hypnotic treatment of an urge to wander. Austr. J. Clin. Exp. -Hypn. 13: 83-95.

Van der Hart, O., Brown, P., and Turco, R. N. (1990). Hypnotherapy for traumatic grief: Janetian and modern approaches integrated. Am. J. Clin. Hypn. 32: 263-271.

Van der Hart, O., Brown, P., and Van der Kolk, B. A. (1989) Pierre Janet's psychological treatment of posttraumatic stress. J. Traum. Stress 2: 379-395.

Van der Hart, O., and Friedman, B. (1989). A reader's guide to Pierre Janet on dissociation: A neglected intellectual heritage. Dissociation 2(1): 3-16.

Van der Hart, O., and Horst, R. (1988). The dissociation theory of Pierre Janet. J. Traum. Stress 2: 397-412. 
Van der Hart, O., and Van der Velden, K. (1987). The hypnotherapy of Dr. Andries Hoek: Uncovering hypnotherapy before Janet, Breuer, and Freud. Am. J. Clin. Hypn. 29: 264271.

\section{TRAUMA-INDUCED PSYCHOSES}

\section{L’hypnose dans l'evaluation et le traitement de psychoses provoquées par traumatismes: la psychothérapie pionnière de $\mathrm{H}$. Breukink et vision plus moderne Onno van der Hart et David Spiegel}

Résumé: Le rôle de I’hypnotisabilité dans le diagnostic différentiel de patients psychotiques est toujours problématique. Darts cet article, les travaux pionniers du psychiatre hollandais H. Breukink (1860-1928), durant les années 20, servent de base pour documenter l'utilité clinique de Yhypnose afin de différentier les patients psychotiques fortement hypnotisables avec une symptômatologie dissociative, des patients schizophrènes. De plus, il existe une longue tradition quant a l'utilisation de la capacité hypnotique dans le traitement des psychoses dissociatives. La façon dont Breukink utilisait l'hypnose pour des fins de diagnostic, de pronostic et de traitement est résumée et discutée a la lumière des conceptions anciennes et modernes. Breukink avançait l’idée que la psychose hystérique était induite par traumatisme, certainement guérissable, et que la psychothérapie utilisant l'hypnose constituait un traitement de choix. L’hypnose était utilisée dans un cadre de thérapie orientée sur les symptômes, comme un état mental confortable et sécurisant et aussi pour faire émerger les souvenirs traumatiques et les intégrar. Pour ce dernier usage, Breukink recommande l'utilisation d'un état de calme mental, autant en hypnose qu'en état d'éveil, et décourage l'expression emotive qu'il considère comme dangereuses chez les patients psychotiques. Dans la discussion, une attention spéciale est accordée au rôle et dangers de l’expression des emotions reliées au traumatisme.

Evaluacion y tratamiento hipnotico de psicosis traumaticas:

la psicoterapia primitiva de H. Breukink y una vision contemporanea Onno van der Hart y David Spiegel

Resumen: El rol de la evaluacion de la hipnotizabilidad en el diagnóstico diferencial de pacientes psic6ticos no ha sido resuelto todavia. En este estudio, el trabajo pionero realizado durante los años 1920 por el psiquiatra holandés H. Breukink (1860-1928) es utilizabo como una evidencia temprana de que la capacidad hipn6tica es clinicamente útil para diferenciar pacientes psic6ticos con sintomatologia disociativa y altamente hipnotizables de los pacientes esquizofrénicos. Además existe una larga tradición en el empleo de la capacidad hipn6tica en el tratamiento de éstas psicosis disociativas. Las maneras en que Breukink utilizó la hipnosis para diagnóstico, pronóstico y tratamiento son repertoriadas y discutidas a las luz de los puntos de vista contemporáneos y de la época. Breukink pensaba que la psicosis histérica era inducida traurnáticamente, ciertamente curable y que la psicoterapia que utilizaba la hipnosis era el tratamiento de elección. Se usaba la hipnosis como una terapia sintomática, como una condición para una mejoria general y para descubrir e integrar recuerdos traumáticos. Para este ultimo propósito Breukink enfatizaba un estado de calma mental, en estado hipnotico y de vigilia, desalentando la expresi6n emocional considerada peligrosa para los pacientes psic6ticos. Se acuerda especial atención en la discusión al rol y peligros de la expresi6n de emociones relacionadas con to traumático. 